\title{
How can air quality affect health?
}

\author{
Jo A Douglass MD FRACP
}

Head, Department of Medicine, Royal Melbourne Hospital, University of Melbourne. Parkville, Vic 3050 .

Director of Research, The Royal Melbourne Hospital

Grattan St, Parkville

Vic 3050

Australia

Phone: 0383444578

Email: jdouglass@unimelb.edu.au

In recent years, Australians have been subject to an unprecedented number of environmental events visibly and materially affecting air quality - from thunderstorm asthma to bushfire smoke. So, what is the evidence that air quality affects health? And, given the likely recurrence of such events, what can be done to mitigate their effects on health outcomes?

Particulate air pollution is monitored world-wide, as concentrations of airborne particles $10 \mu \mathrm{m}$ and $2.5 \mu \mathrm{m}$ in diameter per $\mathrm{m}^{3}$ (PM 10 and PM 2.5). A recent analysis of the associations between PM10 and PM2.5 in 24 countries $^{1}$, showed a significant increase in all-cause, cardiovascular and respiratory mortality attributable to increases in airborne particulates. Australia showed a particularly high increase in daily all-cause mortality of $1.32 \%(95 \% \mathrm{Cl} 0.22$ to 2.44$)$ per day for every $10 \mu \mathrm{g} / \mathrm{m}^{3}$ increase in PM 10.

During the 2019 Australian bushfire season, PM2.5 frequently exceeded the WHO standard of $25 \mu \mathrm{g} / \mathrm{m}^{3}$, with a maximum 24-hour national average PM2.5 on the 14th January 2020 reaching 98.5 $\mu \mathrm{g} / \mathrm{m}^{3} .{ }^{2}$ Modelling based on the known effects sizes of increases in PM2.5 on mortality and morbidity in Australia suggest that $417(95 \% \mathrm{Cl} 153-680)$ excess deaths were likely due to bushfire induced particulate pollution with $1124(95 \% \mathrm{Cl}, 211-2047)$ cardiovascular-related hospitalisations and $2027(95 \% \mathrm{Cl}, 0-4252)$ respiratory hospitalisations. ${ }^{3}$ Systematic analysis of the impacts of

This is the author manuscript accepted for publication and has undergone full peer review but has not been through the copyediting, typesetting, pagination and proofreading process, which may lead to differences between this version and the Version of Record. Please cite this article as doi: 10.1111/imj.15050

This article is protected by copyright. All rights reserved. 
landscape smoke exposure in Australia reveal an increase in hospital presentations for asthma and COPD, most marked when PM 10 exceed $40 \mu \mathrm{g} / \mathrm{m}^{3} 4$.

Biological factors can also affect air quality. Cities in south-eastern Australia have experienced episodes of epidemic thunderstorm asthma (ETSA) ${ }^{5}$ with the Melbourne event of November 2016 exceptionally severe ${ }^{6}$. ETSA occurs when high concentrations of ryegrass pollen fragments are released in a thunderstorm front, causing allergic individuals to suffer from lower respiratory tract symptoms and those with asthma to be at risk of a severe exacerbation ${ }^{7}$. However ETSA is only one feature of a seasonal peak in Victorian asthma emergency attendances occurring in November and December. ${ }^{8}$

These incidents flag the importance of health literacy to environmental factors to guide individual risk management. Specifically, the provision of public information on air quality and how to act when poor or hazardous should be available and rehearsed. The Melbourne Pollen App is widely subscribed and provides information on pollen counts to inform action to prevent seasonal allergic rhinitis and ETSA ${ }^{9}$. Clinicians can also communicate the adverse health impacts of air quality so that risk mitigation strategies are planned, especially for those with heart and lung disease. Given the pervasive adverse consequences of poor air quality, the medical profession has a responsibility to advocate for clean air as a necessity for good health.

\footnotetext{
${ }^{1}$ Liu C, Chen R, Sera F, et al. Ambient Particulate Air Pollution and Daily Mortality in 652 Cities. N Engl J Med. 2019;381(8):705-715. doi:10.1056/NEJMoa1817364

2 Borchers Arriagada N, Palmer AJ, Bowman DM, Morgan GG, Jalaludin BB, Johnston FH. Unprecedented smoke-related health burden associated with the 2019-20 bushfires in eastern Australia [published online ahead of print, 2020 Mar 12]. Med J Aust. 2020;10.5694/mja2.50545. doi:10.5694/mja2.50545

${ }^{3}$ Borchers Arriagada N, Palmer AJ, Bowman DM, Morgan GG, Jalaludin BB, Johnston FH. Unprecedented smoke-related health burden associated with the 2019-20 bushfires in eastern Australia [published online ahead of print, 2020 Mar 12]. Med J Aust. 2020;10.5694/mja2.50545. doi:10.5694/mja2.50545

${ }^{4}$ Walter CM, Schneider-Futschik EK, Knibbs LD, Irving LB. Health impacts of bushfire smoke exposure in Australia. Respirology. 2020;25(5):495-501. doi:10.1111/resp.13798

${ }^{5}$ Lindstrom SJ, Silver JD, Sutherland MF, et al. Thunderstorm asthma outbreak of November 2016: a natural disaster requiring planning. Med J Aust. 2017;207(6):235-237. doi:10.5694/mja17.00285

${ }^{6}$ Thien F, Beggs PJ, Csutoros D, et al. The Melbourne epidemic thunderstorm asthma event 2016: an investigation of environmental triggers, effect on health services, and patient risk factors. Lancet Planet Health. 2018;2(6):e255-e263. doi:10.1016/S2542-5196(18)30120-7

${ }^{7}$ Hew M, Lee J, Susanto NH, et al. The 2016 Melbourne thunderstorm asthma epidemic: Risk factors for severe attacks requiring hospital admission. Allergy. 2019;74(1):122-130. doi:10.1111/all.13609

${ }^{8}$ Silver JD, Sutherland MF, Johnston FH, Lampugnani ER, McCarthy MA, Jacobs SJ, et al. (2018) Seasonal asthma in Melbourne, Australia, and some observations on the occurrence of thunderstorm asthma and its predictability. PLoS ONE 13(4): e0194929. https://doi.org/10.1371/ journal.pone.0194929

${ }^{9}$ The Melbourne Pollen Count: https://www.melbournepollen.com.au/mobile-app/
} 
Over recent years Australians have been subject to an unprecedented number of environmental events materially and visibly affecting air quality, including thunderstorm asthma and bushfire smoke. There is increasing evidence that poor air quality adversely affects health with consequences for mortality and morbidity with measured particulates (PM2.5) in January 2019 frequently exceeding WHO standards. Biological factors can also impact air quality with thunderstorm asthma epidemics evidence of a prime example, the 2016 event being associated with severe impacts on health services. Given these events, consideration needs to be given to environmental health literacy which will support individuals with preexisting illness to recognise and mitigate as far as possible the effects of adverse air quality. Recognising the impact of poor air quality should also urge physicians to advocate for clean air as a necessity. for good health. 
How can air quality affect health?

Jo A Douglass MD FRACP

Head, Department of Medicine, Royal Melbourne Hospital, University of Melbourne. Parkville, Vic 3050.

Director of Research, The Royal Melbourne Hospital

Grattan St, Parkville

Vic 3050

Australia

Phone: 0383444578

Email: jdouglass@unimelb.edu.au

This article is protected by copyright. All rights reserved. 


\section{University Library}

\section{- M M I N E R VA A gateway to Melbourne's research publications}

Minerva Access is the Institutional Repository of The University of Melbourne

Author/s:

Douglass, JA

Title:

How can air quality affect health?

Date:

2020-11-01

Citation:

Douglass, J. A. (2020). How can air quality affect health?. INTERNAL MEDICINE JOURNAL, 50 (11), pp.1403-1404. https://doi.org/10.1111/imj. 15050.

Persistent Link:

http://hdl.handle.net/11343/276562 